Int Arch Allergy Appl Immunol 1990;92:I-VI

\title{
Contents, Vol. 92, 1990
}

\section{No. 1}

Original Paper

Comparison of Conidial and Mycelial Allergens of Alternaria

alternata

Paris, S.; Fitting, C; Latgé, J.P.; Herman, D.; Guinnepain,

$>$ M.T.; David, B 1

Serum Antibodies Reactive with Saccharomyces cerevisiae in 1 Inflammatory Bowel Disease: Is IgA Antibody a Marker for

Crohn's Disease?

Barnes, R.M.R.; Allan, S.; Taylor-Robinson, C.H.; Finn, R.;

Johnson, P.M 9

Nedocromil Sodium Prevents the Release of 15-Hydroxyeico-

satetraenoic Acid from Human Bronchial Epithelial Cells

Exposed to Toluene Diisocyanate in vitro (With 1 color

plate)

Mattoli, S.; Mezzetti, M.; Fasoli, A.; Patalano, F; Allegra, L. 16 Preparation of Allergen Extracts from the Green Alga Chlorel-

la. Studies of Growth Variation, Batch Variation, and Partial Purification

Tiberg, E.; Rolfsen, W.; Einarsson, R 23

Antigenic Analysis of Group I House Dust Mite Allergens

Using Random Fragments of Der p I Expressed by Recom-

binant DNA Libraries

Greene, W.K.; Chua, K.Y.; Stewart, G.A.; Thomas, W.R. 30 Anti-Inflammatory Effects of

Onions: Inhibition of Chemo-

taxis of Human Polymorphonuclear Leukocytes by Thio-

sulfinates and Cepaenes

Dorsch, W.; Schneider, E.; Bayer, T; Breu, W.; Wagner, H. 39 Isolation and Characterization of Rat Carcinoembryonic

Antigen

Kim, J.G.; Abeyounis, C.J 43

Immunohistological Analysis of Nerve Granulomas in Neu-

ritic Leprosy

Narayanan, R.B.; Girdhar, A.; Girdhar, B.K.; Malaviya, G.N. 50 Mouse IgE Response against

Exoantigens of Trypanosoma

cruzi

Gruppi, A.; Pistoresi-Palencia, M.C.; Basso, B.; Vottero-

Cima, E 56

Glomerular CR1 Express in situ Cofactor Activity for Degradation of C3b

Vedeler, C.A.; Matre, R.; Iversen, B.M 
Importance of Mast-Cell-Derived Eosinophil Chemotactic Factor A on Granuloma Formation in Murine Schistosomi-asisjaponica: Evaluation Using Mast-Cell-Deficient W/Wv Mice

Owhashi, M.; Horii, Y.; Ikeda, T.; Maruyama, H.; Abe, T.;

Nawa, Y 64

Antiallergic and Anti-Inflammatory Action of Tioxamast in

Rats. I. Antiallergic Activity in vivo and in vitro

Tarayre, J.P.; Aliaga, M.; Barbara, M.; Tisseyre, N.; Caillol, V;

Delhon, A.; Bruniquel, F.; N'Guyen, X.; Puech, L.; Tisné-

Versailles, J.; Couzinier, J.P 69

Antiallergic and Anti-Inflammatory Action of Tioxamast in

Rats. II. Anti-Inflammatory Action in vivo

Tarayre, IP.; Aliaga, M.; Barbara, M.; Tisseyre, N.; Caillol, V;

Delhon, A.; Bruniquel, F.; N'Guyen, X.; Puech, L.; Tisné-

Versailles, J.; Couzinier, J.P 77

Relationship between LTC4 Generation of Hypodense Eosino-phils and Bronchial

Hyperreactivity in Asthmatic Children

Schauer, U.; Daume, U.; Müller, R.; Riedel, F.; Gemsa, D.;

Rieger, C.H.L 82

Modulation of the Immune Response to Allergens: Phospholi-pase A Degradation Products

Suppress IgG and IgE Response in Mice Pesce, A.J.; Freisheim, J.M.; Litwin, A.; Michael, J. . . . 88

Short Communications

CD 1-Positive Epidermal Langerhans Cells in Regressed Tu-

berculoid and Lepromatous Leprosy Lesions

Narayanan, R.B.; Girdhar, A.; Girdhar, B.K 94

Contact Hypersensitivity Induces Plasma Interleukin 6

Kimber, I.; Cumberbatch, M.; Humphreys, M.; Hopkins, S.J. 97 Interleukin-4 Gene Expression

in High and Low IgE Re-

sponder Mice

Mori, A.; Yamamoto, K.; Suko, M.; Watanabe, N.; Ito, M.;

Miyamoto, T.; Okudaira, H 100

Remarkable Increases of Salivary IgE Levels in Allergic Syndromes

Negretti, F.; Casetta, P 103

I

S. Karger $\cdot$ Medical and Scientific Publishers

Basel · München · Paris · London · New York · New Delhi $\cdot$ Bangkok $\cdot$ Singapore $\cdot$ Tokyo $\cdot$

Sydney

Drug Dosage

The authors and the publisher have exerted every effort to ensure that drug selection and dosage set forth in this text are in accord with current recommendations and practice at the time of publication. However, in view of ongoing research, changes in government regulations, and the constant flow of information relating to drug therapy and drug reactions, the reader is urged to check the package insert for each drug for any change in indications and dosage and for added warnings and precautions. This is particularly important when the recommended agent is a new and/or infrequently employed drug.

All rights reserved. 
No part of this publication may be translated into other languages, reproduced or utilized in any form or by any means, electronic or mechanical, including photocopying, recording, microcopying, or by any information storage and retrieval system, without permission in writing from the publisher or, in the case of photocopying, direct payment of a specified fee to the Copyright Clearance Center (see 'Information for Readers and Subscribers').

(C) Copyright 1990 by S. Karger AG, P.O. Box, CH- 4009 Basel (Switzerland) Printed in Switzerland by Buchdruckerei Basler-Zeitung AG, Basel

Contents

$\mathrm{V}$

No. 3

Original Paper

ı A Method for Evaluating Anti-Allergic Drugs by Simultaneously Induced Passive Cutaneous Anaphylaxis and Mediator Cutaneous Reactions

Koda, A.; Miura, T.; Inagaki, N.; Sakamoto, O.; Arimura,

A.; Nagai, H.; Mori, H 209

IgG4 Antibodies in Hay Fever Patients. Difference in IgG4

Response to Tree Pollen and Grass Pollen Allergens

Chernokhvostova, E.V.; Kotova, T.S.; German, G.P.;

Atovmian, O.I 217

IgE Suppressor Factor Induced by Phytohemagglutinin

Astorquiza, M.I.; Cisternas, C 223

Mapping of Bet v I Epitopes by Using Murine Monoclonal Antibodies Marc-Series, I.; Boutin, Y.; Vrancken, E.R.; Hébert, J. . . 226

Histochemical Heterogeneity of Human Mast Cells: Disease-Related Differences in Mast Cell

Subsets Recovered by Bronchoalveolar Lavage

Walls, A.F.; Roberts, J.A.; Godfrey, R.C.; Church, M.K.;

Holgate, S.T 233

Effect of Oral or Parenteral Sensitization to Cow's Milk on

Mucosal Permeability in Guinea Pigs

Heyman, M.; Andriantsoa, M.; Crain-Denoyelle, A.M.;

Desjeux, J.F 242

Elevated Concentrations of Salivary Secretory Immunoglobu-lin A Anti-Cow's Milk Protein in Newborns at Risk of Allergy

Renz, H.; Vestner, R.; Petzoldt, S.; Brehler, C; Prinz, H.;

Rieger, C.H.L 247

Hyposensitization Therapy with Whole Pollen Extract or Puri

fied Allergens Monitored by Immunoblotting

Jarolim, E.; Matthiesen, F.; Stahl Skov, P.; Tejkl, M.;

Oesterballe, O.; Poulsen, L.K 254

Protective Milk O Antibodies Induced in Guinea Pigs by Par

enteral Shigella Ribosomal Vaccine

Chernokhvostova, E.V.; Lyubinskaya, M.M.; Belkin, Z.P.;

Levenson, V.I 265

Induction of Suppressor Cell Activity in Normal Peripheral Blood Mononuclear Cells by Sera from Predialytic Uremic Patients 
Modai, D.; Berman, S.; Weissgarten, J.; Klinovsky, E.;

Cohn, M.; Averbukh, Z 268

Influence of IgE Fragments on IgE Determination

Vassella, C.C.; de Week, A.L.; Stadler, B.M 272

Mast Cell Activation in Sterile Bladder and Prostate Inflammation (With 1 color plate)

Theoharides, T.C.; Flaris, N.; Cronin, C.T.; Ucci, A.;

Meares, E 281

Observations on NK Cells, K Cells and on Their Function a Long Time after Posttraumatic

Splenectomy Demeter, J.; Pálóczi, K.; Lehoczky, D.; Benczur, M. . . 287

Immunoglobulin E Responses and Lung Pathology Resulting from Aerosol Exposure of Calves to Repiratory Syncytial Virus and Micropolyspora faeni

Gershwin, L.J.; Dungworth, D.L.; Himes, S.R.; Frieberts-

hauser, K.E 293

Differential IgE Receptor Development on Rat Tissue Cul

tured Mast Cells

Hu, W.; Chan, B.M.C.; Froese, A 301

Seasonal Variation of the Conjunctival Provocation Test, To

tal and Specific IgE in Children with Birch Pollen Allergy

Möller, C; Elsayed, S 306

Allergens of Horse Epithelium. I. Physicochemical and Immu-nochemical Characterization of

Five Different Horse Epithelium Raw Materials Used for Allergen Extract Preparation

Franke, D.; Maasch, H.J.; Wahl, R.; Schultze-Werning-

haus, G.; Bretting, H 309

Selective Alterations in Natural Killer Cell Subsets in Patients with Atopic Dermatitis

Wehrmann, W.; Reinhold, U.; Kukel, S.; Franke, N.;

Uerlich, M.; Kreysel, H.W 318

Significance and Specificity of Anti-SSA/Ro Antibody in Pa

tients with Bullous Disorders

Deng, J.-S.; Lee, P.Y.-P.; Fratto, J.L 323

Announcement

328

IV

Contents

No. 2

Original Paper

In vitro Immunosuppressive and Anti-Phagocytic Properties of the Exopolysaccharide of Mucoid

Strains of Pseudo-monas aeruginosa Mai, G.T.; Seow, W.K.; Mc Cormack, J.G.; Thong, Y.H.

105

Correlation of sCD23 Release and Immunoglobulin (E, A, G, M) Synthesis by Peripheral Blood Lymphocytes of Atopic Patients

Bujanowski-Weber, J.; Knöller, I.; Pfeil, T.; Luther, H.;

Altmeyer, P.; König, W

Presence of IgA and IgG Antigliadin Antibodies in Healthy Adults as Measured by Micro-

ELISA. Effect of Various Cutoff Levels on Specificity and Sensitivity When Diagnosing Coeliac

Disease Grodzinsky, E.; Hed, J.; Liedén, G.; Sjögren, F.; Strom, M. 119 
Endotoxin-Induced Auto-Immunity in Mice. III. Comparison of Different Endotoxin Preparations Bloembergen, P.; Hofhuis, F.M.A.; Hoi, C; van Dijk, H. 124

Human IgE, IgG and IgA Antibody Responses to T101, a

Murine Monoclonal Antibody against Human Lympho

cytes: Implications for Pathogenesis, Risk and Avoidance

of Adverse Immunologic Reactions

Dykewicz, M.S.; Cranberg, J.A.; Patterson, R.; Rosen, S.T.;

Shaughnessy, M.A.; Zimmer, A.M 131

Bronchial Responsiveness to Mite Allergen in Atopic Dermatitis without Asthma

Dohi, M.; Okudaira, H.; Sugiyama, H.; Tsurumachi, K.;

Suko, M.; Nakagawa, T.; Morita, Y.; Ito, K.; Nakayama, H.;

Miyamoto, $\mathrm{T} 138$

Inhibition of 5-HETE, LTB4 and LTC4 Formation by Azelas-tine in Rat Mixed Peritoneal Cells

Chand, N.; Pillar, J.; Nolan, K.; Diamantis, W.; Sofia, R.D. 143

Subepithelial Hydrostatic Pressure May Regulate Plasma Exudation across the Mucosa Perrson, C.G.A.; Erjefált, I.; Gustafsson, B.; Luts, A. . . 148

Shared Allergenic Activity in Asian (Blattella asahinai), German (Blattella germanica), American (Periplaneta america-na), and Oriental (Blatta orientalis) Cockroach Species Helm,

R.M.; Squillace, D.L.; Jones, R.T.; Brenner, R.J. . 154

K-Channel Blocking Drugs Induce Histamine Release and

45Ca Uptake in Isolated Mast Cells

Eleno, N.; Botana, L.; Espinosa, J 162

IgE-Mediated Allergic Reactions to Potatoes

Wahl, R.; Lau, S.; Maasch, H.J.; Wahn, U 168

Obtention of Monoclonal Antibodies against Human IgG4

using Two Different Immunization Strategies: Develop

ment of a Biotin-Based ELISA for IgG4 Quantitation

Jimeno Nogales, L.; Carreira, J.; Lombardero, M 175

Gut Hypersensitivity Reactions in Guinea Pigs following Vac

cination or Infection with Trichostrongylus colubriformis

Ward, C.W.; Wagland, B.M 183

Characteristics of MTT as an Indicator of Viability and Respi

ratory Burst Activity of Human Neutrophils

Pruett, S.B.; Loftis, A.Y 189

Identification of Soybean Allergens by Immunoblotting with

Sera from Soy-Allergic Adults

Herian, A.M.; Taylor, S.L.; Bush, R.K

Elevation of Neutrophil Chemotactic Activity in the Human

Serum and the Decreased Number of Neutrophils after

Platelet-Activating Factor Inhalation

Miyagawa, H.; Nabe, M.; Hopp, R.J.; Agrawal, D.K.;

Bewtra, A.K.; Townley, R.G 199

Histamine Release Induced by Radiographic Contrast Media. Comparison between Pulmonary and Peritoneal Mast Cells Derived from Normotensive and Spontaneously Hypertensive Rats Amon, E.U.; Ennis, M.; Lorenz, W.; Schnabel, M.;

Schneider, C 203 
VI

Contents

No. 4

Original Paper

Substance P-Induced Histamine Release from Human Baso-

phils, Skin and Lung Fragments: Effect of Nedocromil

Sodium and Theophylline

Louis, R.E.; Radermecker, M.F 329

Cytokine Control of Peripheral-Blood CD23 Expression and

sCD23 Release: Differential Regulation by IL-2 and IL-4

Fischer, A.; Pfeil, Th.; König, W 334

Manipulation of Macrophage Migration Inhibition/Stimulation Responses by Adjuvants and Interleukins

MacSween, J.M.; Rajaraman, R.; Rajaraman, S 343

Rat Mast Cell Granules Reacting with a Mouse Monoclonal

Antibody M6764 which Recognizes the Same Epitope of a

Mouse Monoclonal Antibody HNK-1

Kurosawa, M.; Okayama, Y.; Kobayashi, S.; Obata, K. . 349 Differences in Migration Inhibitory

Factor Production by

C57B1/6 and BALB/c Mice in Allergic and Irritant Contact

Dermatitis (With 1 color plate)

Malorny, U.; Goebeler, M.; Gutwald, J.; Roth, J.; Sorg, C. 356 Protection of Rats against

Schistosoma mansoni Infection

Induced by Platelets Stimulated with the Murine Recombi-

nant Tumor Necrosis Factor Alpha

Damonneville, M.; Pancré, V.; Capron, A.; Auriault, C. . 361 Drug-Induced Fever: A Clinical

Report and Challenge Test

with Calcium Dobesilate

Puyana, J.; Fraj, J.; De La Hoz, B.; Davila, I.; Vergara, C;

Cuesta, J 364

Histamine Release from Basophils after in vivo Application of

Recombinant Human Interleukin-3 in Man

Merget, R.D.; Maurer, A.B.; Koch, U.; Ganser, A.; Ottman,

O.G.; Schultze-Werninghaus, G.; Seipelt, G.; Zachgo, W.;

Hoelzer, D.; Meier-Sydow, J 366

Presence of Felis domesticus Allergen I in the Cat's Salivary

and Lacrimal Glands

van Milligen, F.J.; Vroom, T.M.; Aalberse, R.C 375

Synergistic Activation of Human Natural Killer Cell Cytotox-

icity by Histamine and Interleukin-2

Hellstrand, K; Hermodsson, S 379

Follicle Lysis in HIV-Free Lymphoid Tissues

Shiota, M.; Toyama, K; Mori, S 390

Possible Role for Platelet-Activating Factor in Neutrophil

Infilatration in Allergic Inflammation in Rats 
Watanabe, M.; Sugidachi, A.; Omata, M.; Hirasawa, N.;

Mue, S.; Tsurufuji, S.; Ohuchi, K 396

Inhibition of Endogenous Leukotriene-Mediated Lung Anâ-phylaxis in Guinea Pigs by a Novel Receptor Antagonist ONO-1078

Ishii, A.; Nakagawa, T.; Nambu, F.; Motoishi, M.; Miya

moto, $\mathrm{T} \quad 404$

Epitope-Specific Regulation of the Antibody Response against

Alpha-Lactalbumins in the Mouse

Horiuchi, T.; Yagi, J.; Asano, Y.; Tada, T 408

Eosinophil Accumulation in the Rat Pleural Cavity after Mast Cell Stimulation with Compound 48/80 Involves Protein Synthesis and Is Selectively Suppressed by Dexametha-sone

Martins, M.A.; Pasquale, C.P.; e Suva, P.M.R.; Cordeiro,

R.S.B.; Vargaftig, B.B 416

Inhalation Exposure to Respiratory Sensitising Chemicals

Down-Regulates Guinea Pig IgE and Pulmonary Re

sponses

Dearman, R.J.; Botham, P.A 425

Susceptibility to Proteolipid Apoprotein and Its Encephalito-genic Determinants in Mice Endoh, M.; Kunishita, T;Nihei, J.; Nishizawa, M.;Tabira, T 433

Drugs as Allergens: An Immunoassay for Detecting IgE Anti

bodies to Cephalosporins

Harle, D.G.; Baldo, B.A

445

Author Index 